\title{
The need for new technology to optimise the engineering design of ground support systems in underground mines
}

\author{
Y Potvin Australian Centre for Geomechanics and The University of Western Australia, Australia
}

\begin{abstract}
This keynote briefly describes the current ground support design methods and design practices at Canadian and Australian mine sites, based on a comprehensive benchmarking review performed as part of the Ground Support System Optimisation (GSSO) research project from 2013-2017.

Following the review of current practice, major gaps are identified and the requirement for developing new technologies to enable the optimisation of ground support systems in the future are proposed.

The discussion is divided into three domains of ground support applications: normal, rockburst-prone and squeezing ground conditions.
\end{abstract}

Keywords: ground support, rockburst, squeezing ground

\section{Introduction}

During the last two decades the mining industry operating in developed countries has made significant gains in reducing the risk of rockfalls. Statistically, rockfall is no longer one of the main causes of fatal accidents in underground metal mines. Potvin (2010) estimated, based on statistics published by the Minerals Council of Australia, that the risk of a rockfall fatality in Australian underground metal mines was less than one in 32,000 per year, compared to approximately one in 2,500 in Western Australia during the decade 1990-2000 (Lang \& Stubley 2003). This was seven years ago and, despite the lack of published statistics since then, it is believed that further incremental safety gains have been made. Having the opportunity to visit mines in many countries, it is my observation that ground support practices in Australia are conservative, but these conservative practices are also the main reason for an outstanding safety improvement.

It is a legitimate goal to optimise ground support without reducing safety. If one contemplates opportunities for optimising ground support, it is essential to assess how conservative our designs are. Unfortunately, it is not so easy to come up with a definitive answer. Our capability to quantify ground support reliability is deficient and, in fact, our engineering design approaches, in general, are deficient.

This paper will examine the current engineering practices of designing ground support systems, identify what I perceive as the main gaps and outline the need for future technology development. The discussion will be divided into three domains of ground support applications: normal, rockburst-prone and squeezing ground conditions. A significant proportion of the background information presented here has been gathered by a team of researchers during the Australian Centre for Geomechanics research project entitled 'Ground Support System Optimisation' (GSSO1), but the views expressed are my own.

\section{Ground support design in normal ground conditions}

Ground conditions in underground mines can vary broadly and, as such, it could be difficult to define boundaries around so-called 'normal' ground condition. For the purpose of this paper, I will consider conditions to be normal if they are not rockburst-prone or subject to squeezing behaviour. 


\subsection{Current engineering approach to ground support design in normal conditions}

Unlike civil geotechnical engineering design, where the process follows the sequential steps of gathering data, performing design analysis, implementing the design and monitoring the design outcome, the design process of ground support systems in mines evolves continuously as a result of changes in ground conditions throughout the mine life.

It is during the scoping and feasibility studies that the first pass of engineering ground support design is performed. At that stage, the main purpose of the design is to estimate ground support costs and the installation cycle time in order to establish the mining schedule and assess the viability of the mining project. This preliminary support design will also provide a starting point for the development mining to proceed, with the realisation that modifications will be likely once more and better quality data become available.

At this stage, especially in greenfields projects, the geotechnical data source is entirely from diamond drill core and, as such, there are obvious limitations as to how this data represents the in situ ground conditions. Hence, the problem being data limited, there is no need to apply sophisticated support design tools, such as numerical modelling, at this stage. The application of simple but robust empirical methods are more relevant.

Potvin and Hadjigeorgiou (2015) have found from a comprehensive survey of Canadian and Australian mines (this is referred to as 'the industry survey' in this paper), that approximately $75 \%$ of the mines relied on the Grimstad and Barton (1993) chart based on the Norwegian Geotechnical Institute (NGI) Q classification (Figure 1), for the design of ground support systems. Potvin and Hadjigeorgiou (2016) also identified numerous flaws in applying an empirical method developed for civil engineering to mining projects, including:

- Mining excavations often go through significant stress changes during their service life.

- Certain support techniques, such as mesh, are widely used in mining, but they are not part of the Grimstad and Barton recommendations. Conversely, support techniques, such as cast concrete lining, are very rarely used in mining, but are part of the recommendations.

- The bolting pattern in the recommendations only specifies spacing, instead of density, and was derived from a widespread and highly variable civil engineering database.

- The range in size and ground condition from mining excavations only occupies a very small area of the Grimstad and Barton chart, as pointed out by Palmstrom and Broch (2006).

- Excavation support ratio (ESR) alone is not sufficient to reflect the differences in conservatism between mining and civil excavations. ESR has been applied inconsistently by the mining industry.

- The Grimstad and Barton chart was specifically designed based on the updated stress reduction factor (referred to as $S R F_{93}$ ). This has been largely ignored by the mining industry and the original stress reduction factor (SRF74) is still widely used with the chart.

For the large majority of mines, the preliminary ground support design estimation from the Grimstad and Barton chart (Figure 1) is gradually modified, purely based on experience, as new ground conditions are encountered. These modifications result in a series of ground support standard engineering drawings, where ground support systems are adapted to the different ground conditions and type of excavations at each mine site. These are generally documented in the ground control management plan (GCMP). 


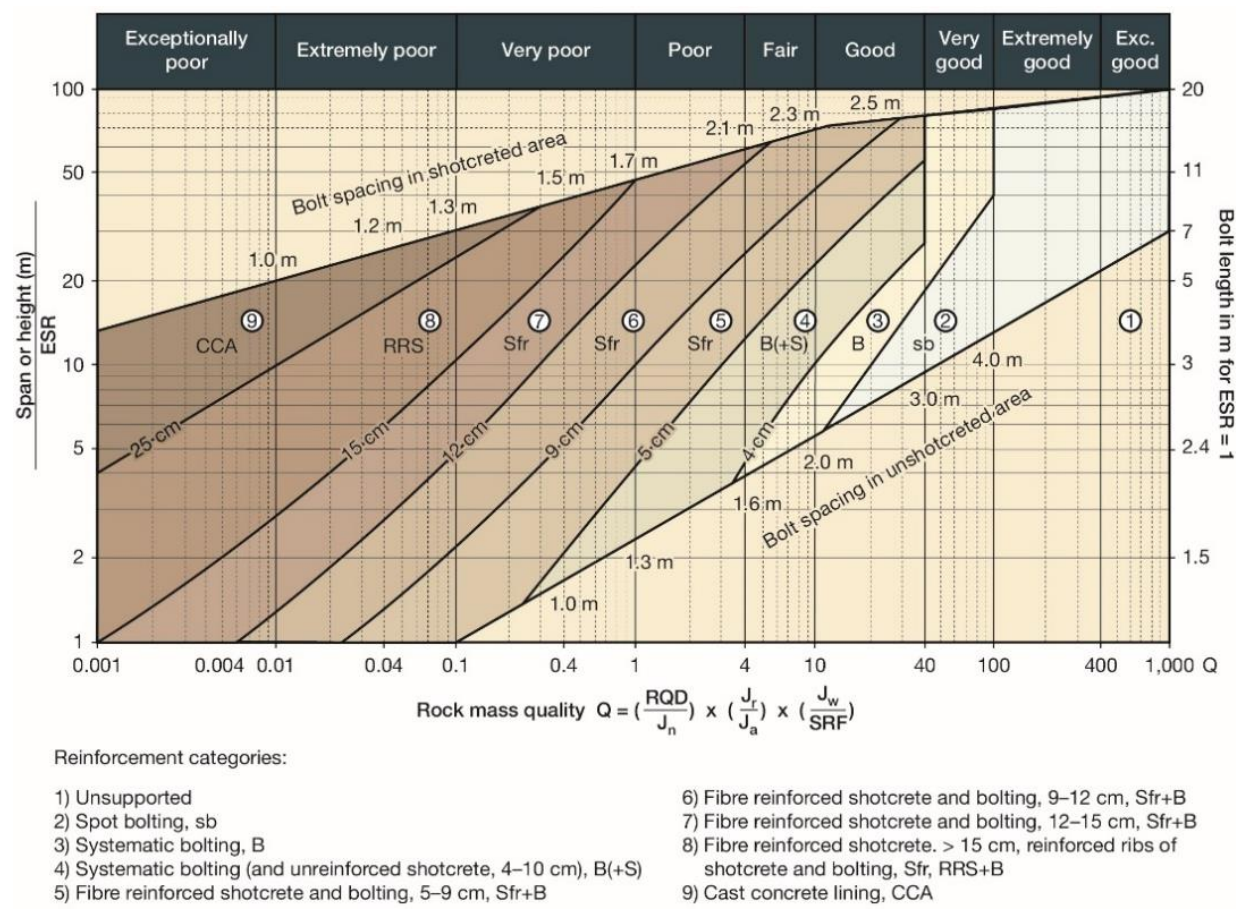

Figure 1 Rock mass classification - permanent support recommendation based on Q (after Grimstad \& Barton 1993)

The industry survey also revealed that the software Unwedge (Rocscience Inc. 2012) is another ground support engineering technique widely applied (by $56 \%$ of the mines surveyed). Unwedge is mainly applied once mining has started and structural data is available. In particular, it is used to calculate the weight of the largest possible wedge and to verify that the existing support design can cater for it. Unwedge is particularly useful for designing ground support, often involving cable bolts, in large intersections.

\subsection{Gaps in the current engineering approach to ground support design in normal conditions}

The widespread application of the empirical civil engineering-based Grimstad and Barton chart to mining problems at feasibility studies has been identified as an obvious gap. Potvin and Hadjigeorgiou (2016) proposed an alternative empirical approach entirely based on data of mining practices from Australia and Canada (Figure 2), but this proposed method is very new and is only starting to be applied in mining.

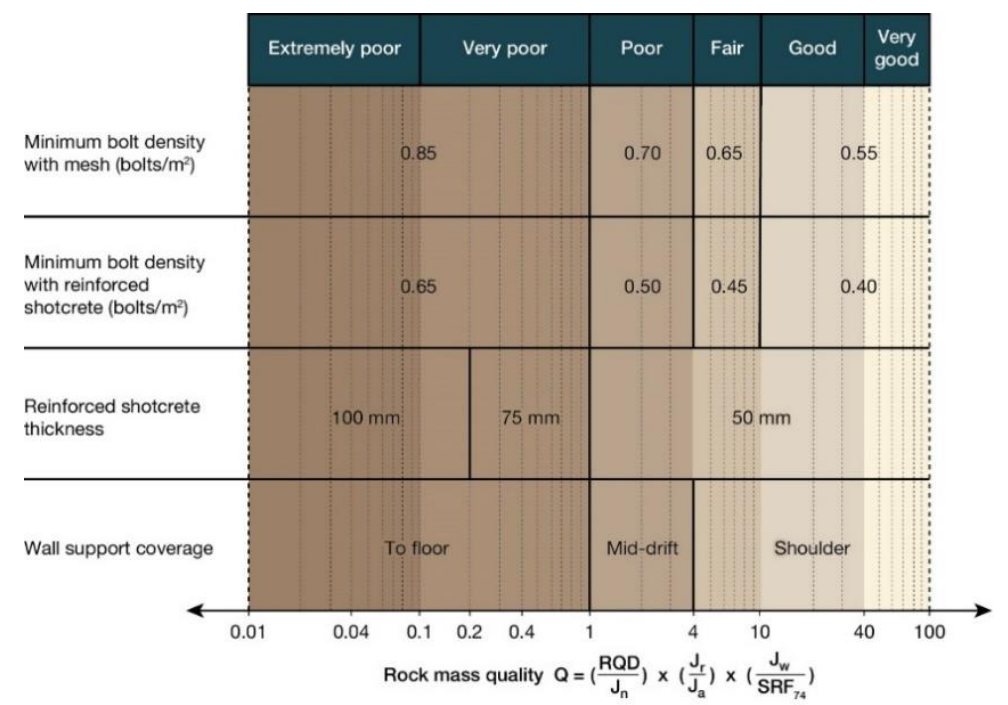

Figure 2 Ground support guidelines for mine drives of 4-6 $\mathrm{m}$ span 
Another gap is the lack of engineering design approach in the optimisation of ground support after the feasibility study is completed. Numerical modelling is a widely used technique in mining geomechanics, but it is seldom applied to the problem of ground support design (less than $20 \%$ of mines from the industry survey). Sweby et al. (2016a) conducted a comprehensive investigation on the capabilities of sophisticated numerical codes to explicitly model ground support and concluded that:

"In regards to the applicability of numerical modelling for ground support design, this study has shown the following;

- This type of modelling requires a significant amount of time and expertise which is generally not available at mine sites in practice;

- The correlations achieved is realistic for some parameters, but somewhat erratic for others;

- At the early stages of design, no verifiable data are available for correlation/calibration and thus results may not be reliable;

- The tool itself has the capability to reproduce the load and displacement experienced by ground support under controlled conditions such as this monitoring study;

In summary, it is difficult to conclude that this type of numerical modelling could be used

for explicit design of ground support systems at mine sites given the complexities in setting up, running and calibrating the model. The sensitivity of the outputs to input data variability is also a major concern when using numerical models for design purposes."

The third major gap, in my view, is the lack of criteria to decide on the adequacy of ground support systems. In many instances mine operators are aware that they are overdesigning ground support, but what criteria can they use to justify a reduction, or even a change in ground support approach? The Factor of Safety (FS) has been the criteria of choice in the past. However, using FS as a criteria defining the adequacy of a design, the designer does not explicitly account for the variability and uncertainty of the input parameters and other design constraints and, as such, is assuming that the reliability of the design is acceptable without having any knowledge of it (Wesseloo \& Joughin 2017).

Probabilistic techniques in my view provide the best opportunity to investigate, based on a sound engineering approach, the effect of modifying ground support on safety, whilst accounting for the variability and uncertainty of the input data and other design constraints. In particular, the probability of failure can be calculated for different designs and provide an arbitrary criteria to decide on what is a tolerable risk and an acceptable design.

\subsection{Ground support design in normal conditions - where to from here?}

A new empirical approach for feasibility studies has been proposed (Figure 2) and needs to be tested, applied and further developed. This will take some time but there is no particular obstacle to fill this gap.

The explicit numerical modelling of ground support will undoubtedly see further development in the future. My concern with this approach is the requirement for a rigorous calibration and validation of the models which, as demonstrated by Sweby et al. (2016a, 2016b), is costly, time-consuming and difficult to achieve. There is always a temptation with numerical models to produce answers without having achieved proper calibration and validation. It is early days in the development of explicit modelling of ground support and it remains the domain of experts. In the long-term, the industry will benefit from further developing the technique, but mines using this approach will need to perform appropriate calibration that goes beyond correlation to simple observations.

Regarding the third gap on the lack of criteria for adequate design, this is a very new field of application of probabilistic methods for ground support design in mines. Literature on this specific subject is not common and only a few papers are available, including: Oreste (2005), Langford \& Diederichs (2011), Langford et al. (2012), Langford \& Diederichs (2013), Low and Einstein (2013) and Joughin (2017). Some work has been done on this subject under the GSSO1 project and is due for publication at the end of 2017 (Wesseloo \& Joughin 2017). 
In the future, the industry needs to go beyond the FS approach and use acceptability criteria based on probability of failure and eventually on a risk-based approach which accounts for exposure of people and assets and consequences of failures, focusing on minimising potential losses.

One of the first barriers to overcome is the need for user-friendly tools to account for the variability of the numerous input parameters required for ground support design. The variability of rock mass and stress parameters will influence the demand on ground support, whilst the variability of ground support performance in different conditions and due to quality control during installation will affect the capacity of the support system. Some of these tools are currently being developed as apps within the software mXrap (Harris \& Wesseloo 2015) and will be implemented at mine sites in the near future.

Techniques for performing probabilistic calculations (Baecher \& Christian 2003), including Monte Carlo (MC) simulation, point estimate method (PEM), response surface method (RSM) and response influence factor method (RIF), tend to be generally unknown from the mining engineering and mining geomechanics community. They are relatively mathematically complex when applied to many parameters, and the lack of user-friendly tools is also a barrier to their application to the ground support design problem.

The next few years should see engineers and consultants start applying simple probabilistic tools to account for the variability of input parameters and quantify the reliability of the design, as a first step towards going beyond the FS criteria for design of ground support.

\section{$3 \quad$ Ground support design in rockburst-prone conditions}

Every mine experiences seismicity, but sometimes the seismicity is small, inconsequential and undetected. It is when seismicity reaches a point where it causes damage to supported underground excavations that mines are operating in what I classify as rockburst-prone conditions. In these conditions, the design approach for ground support will not only need to account for normal or static loading conditions, but also will need to cater for dynamic loading from seismic events.

\subsection{Current engineering approach to ground support design in rockburst-prone conditions}

As a result of a major research project, Kaiser et al. (1996) published a comprehensive methodology for the design of ground support under rockburst-prone conditions (often referred to as the Canadian Rockburst Research Program (CRRP) method). This remains the best known, if not the only deterministic approach available to date, and is applied in many mines. I understand that Kaiser and co-workers are currently updating their method but this is not available at the time of writing this paper.

One of the major shortcomings of the original CRRP method was the lack of data quantifying the dynamic capacity of ground support elements. Since the publication of this method, a large proportion of the ground support and rockburst research has concentrated on developing drop testing facilities and performing dynamic tests on ground support products used in mines. Literature on this topic is available from different conference series including Deep and High Stress Mining, Ground Support in Mining and Underground Construction, and Rockburst and Seismicity in Mines. A compilation of the published testing on reinforcement is summarised in Figure 3, and on surface support in Figure 4. 


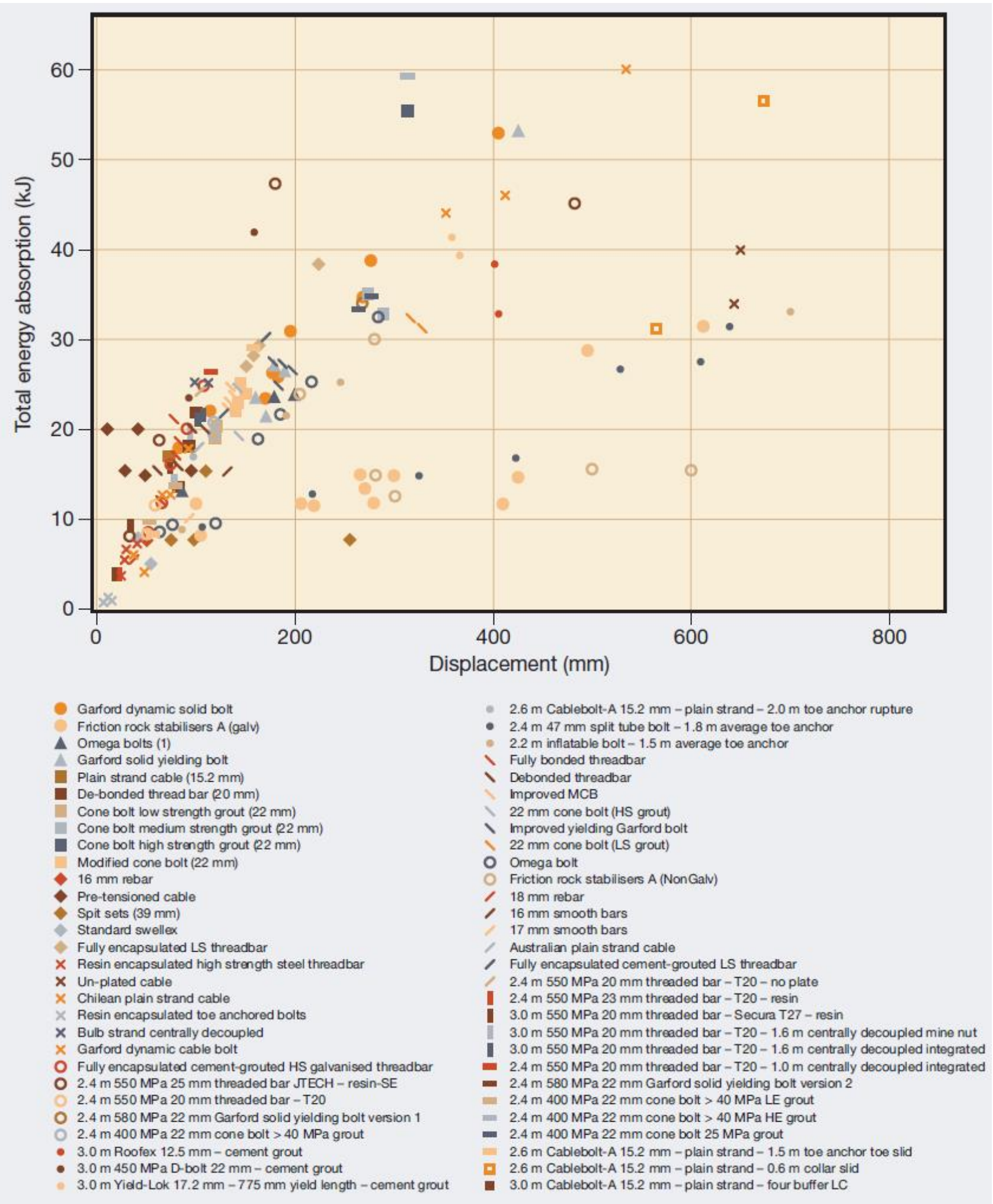

Figure 3 Compilation of drop tests performed on various reinforcement elements and reported by the following authors: Ortlepp and Stacey (1998); Player et al. $(2008 a, 2009,2013)$ and Villaescusa et al. $(2008,2010,2013 a, 2014)$ (modified after Potvin et al. 2010) 


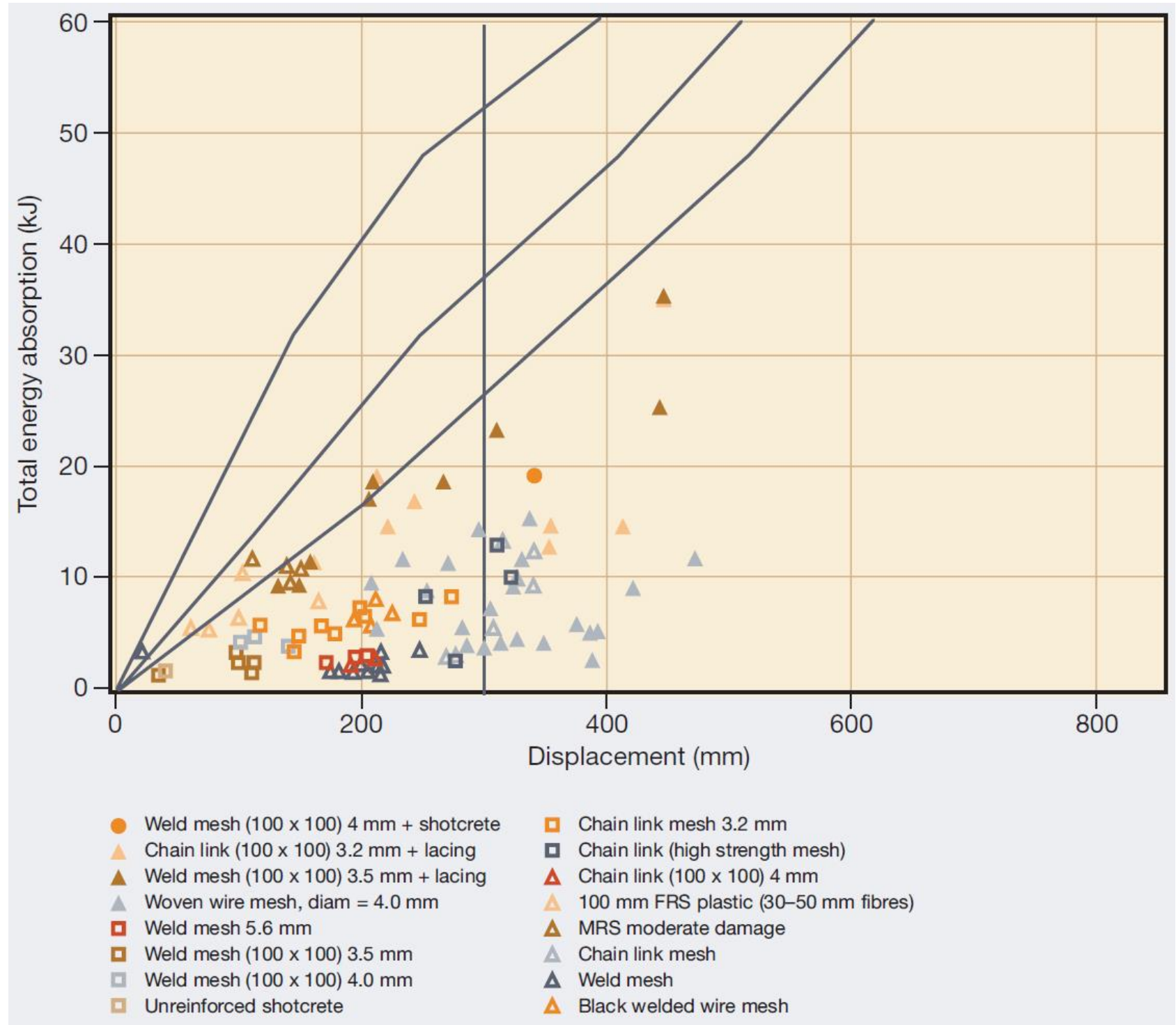

Figure 4 Compilation of drop tests performed on various surface support elements and reported by the following authors: Kaiser et al. (1996), Ortlepp and Stacey (1997), Player et al. (2008b), Villaescusa et al. $(2010,2013 b)$ (modified after Potvin et al. 2010)

It must be emphasised that although these tests are index tests and are particularly useful in comparing ground support product performance under an impact test, the data should be used with care to quantify the dynamic capacity of support elements. It does not simulate the rockburst mechanism adequately - neither the interaction between the support element nor the rock mass being deformed and broken by the seismic waves.

A number of empirical techniques have also been proposed (Heal 2010; Mikula 2012; Morissette \& Hadjigeorgiou 2017), but all of them have limitations and are not widely used in the industry.

It is also worth mentioning that suppliers have engaged in significant research and development programs to develop new yielding and high energy absorption products that had a very positive impact in mines to mitigating rockburst hazard. These important developments are not discussed here, as this keynote paper concentrates on engineering design issues rather than new ground support products. 


\subsection{Gaps in the current engineering approach to ground support design in rockburst-prone conditions}

Rockbursting is a very complex phenomena that remains poorly understood. Consequently, developing a set of equations that represent adequately the mechanisms involved in the seismic waves propagating through a mine, and the resulting damage process incurred by supported excavations, is beyond the current state-of-the-art in geomechanics.

This was stated in Stacey's 2012 keynote (Stacey 2012) where he argued that ground support design under dynamic loading conditions is a clear case of design indeterminacy. There are still many unknowns with regard to the demand and the capacity of ground support subjected to dynamic loading.

\subsubsection{Gaps in estimating dynamic demand on ground support}

Potvin and Wesseloo (2013) have discussed some of the shortcomings in estimating the dynamic demand on ground support. For far field seismic events, the seismic waves travelling from the source to excavations is subjected to complex reflection and refraction patterns due to interferences caused by the network of mine openings, the fault systems and the contrast in rock mass properties (hence a contrast in seismic velocity). Despite the fact that dynamic models exist to simulate reflection and refraction, they have not often been applied to model such a complex problem, nor have they been calibrated and validated for mining environments.

Reflection and refraction is less of a concern for near field events, however, our understanding of ground motion in the near field is not very advanced, as measurements in the near field of significant seismic events are very difficult to achieve.

A further complication in estimating dynamic demand arises from what a number of authors have called 'the site effect', where ground motion is believed to be amplified as it reaches the surface of excavations. Milev et al. (1999) estimate that the peak particle velocity (PPV) can be amplified by four to 10 times the expected value due to the site effect. Based on earlier work completed by Durrheim et al. (1998) and Hagan et al. (1999), Durrheim (2012) also suggested that the ground motion at the surface of excavations in South African mines can be amplified by a factor of four to ten-fold. He also proposed, as a possible explanation for the site effect, that the amplitude of the stress waves can be expected to double at the surface of an excavation.

Another possible and poorly understood phenomenon contributing to dynamic loading is the effect of high levels of local induced stress combined with the brittleness of the rock mass surrounding excavations. This may result in high levels of strain energy stored near excavation which can be readily released from blasting or surrounding seismic activities (Kaiser \& Cai 2013).

The current methods to assess ground motion at the excavation surface to estimate the dynamic demand on ground support do not adequately take into account the aforementioned complex phenomena and use simple empirical scaling laws to attenuate the velocity with the inverse of the distance between the source of the event and the excavation.

\subsubsection{Gaps in estimating dynamic capacity of ground support systems}

Despite the significant developments in testing ground support to quantify dynamic capacity, several gaps remain to be filled before reliable estimates of the dynamic capacity of ground support systems can be made.

It is well recognised and stated by Stacey (2012) that data on dynamic capacity from dynamic testing are not a true representation of rockburst loading. However, one could argue that drop testing data plays a similar role to static pull testing in the lab, which is often used for designing static support.

The industry seems to accept that drop test data on support elements can be used as approximate dynamic capacity values. Nevertheless, the fundamental question remains on how to combine the capacity of reinforcement and surface support elements to define the capacity of the support system. The minimal value would be to consider only the capacity of the weakest part of the system, generally the surface support, 
whilst the maximum value would be adding the reinforcement and surface support dynamic capacity. The reality is somewhere in between, but the range between the minimum and the maximum is large, and different conditions would likely lead to different values within this range. A methodology to combine the dynamic capacity of reinforcement and surface support to estimate the dynamic capacity of support systems is a major gap that needs to be addressed.

\subsection{Ground support design in rockburst-prone conditions - where to from here?}

As mentioned before, the methodology proposed by Kaiser et al. (1996) is used at some mine sites, but given the numerous gaps described in the previous sections, many assumptions and oversimplifications are required when applying the method. There is a need to systematically address these gaps, but this will likely require several years of dedicated funded research.

Until science advances our current understanding of demand and capacity of ground support subjected to dynamic loading, a deterministic approach will remain flawed. In this situation, empirical design methods can assist in filling the gap until science sheds new light on the poorly understood mechanisms.

During the last decade there have been at least three significant studies involving the collection of rockburst data, from which statistical and empirical relationships were developed to assist in the selection of dynamic resistant support.

First, Heal (2010) collected 254 cases of rockburst damage observations and proposed the rockburst damage potential (RDP) method (Figure 1) to assess the probable location and level of damage associated with an estimated 90 percentile spatial PPV distribution.

The second major study is documented in Morissette et al. $(2012,2014)$ and Morissette and Hadjigeorgiou (2017) who collected 323 cases of rockburst damage in three mines in the Sudbury Basin, Canada. The authors have also performed interesting statistical and empirical analyses on this carefully collected database. Although the methodology is transferable to all mines, the support design recommendations from this study are only applicable to the three mines that provided data.

In the third major study reported in Mikula (2012) and Mikula and Gebremedhin (2017), 341 case studies of seismically induced damage were documented from four mines in Australia. An empirical charting technique specific to individual mines allowing to relate ground support, seismic event magnitude and damage intensity was proposed.

One very important lesson learnt throughout these studies is the importance of collecting accurate rockburst damage data, as all rockburst damage can probably not be treated in the same way. For example, lower wall and floor damage is generally weakly, if at all, supported, whilst damage to the roof and shoulders is often strongly supported. Characterising the damage by tonnes and cubic metres alone can be misleading. Furthermore, a few cubic metres from the roof can have disastrous consequences, whilst the lifting (without ejections) of several cubic metres from the lower wall may have minimal consequences. Damage from far field events is strongly affected by the reflection and refraction of the seismic waves whilst the near field events are not. Identifying which part of the ground support system that has failed is also a very important piece of data often ignored in the past data collection.

The power of empirical techniques lies in the quality, quantity and variety of data, and a lot has been learnt about rockburst data gathering during the three aforementioned studies. In particular, we now know much more on what data is useful and how to characterise rockburst damage.

One of the major outcomes, and key to the success of improving our empirical ground support design methods in rockbursting conditions, is to take advantage of the learnings from the previous studies in the development and implementation of a new standard, efficient and user-friendly way to collect rockburst damage data. Templates and tools need to be created to facilitate some standardisation of rockburst data collection at mine sites, including automatic reporting. This will result in a new and improved database of rockburst damage that can be used to further develop empirical methods. 


\section{$4 \quad$ Ground support design in squeezing ground conditions}

Squeezing ground conditions can be the result of very weak isotropic rock mass that flows in a quasi-plastic behaviour, or, alternatively, is caused by a highly foliated and highly anisotropic rock mass. The weak isotropic cases are common to civil tunnelling, whilst the vast majority, but not all, of documented cases of mines experiencing squeezing ground have been dealing with the anisotropic foliated rock mass. For this reason, much of the recent progress in relation to ground support in squeezing conditions in mines have dealt with foliated squeezing ground.

Squeezing ground in mines may exhibit deformation between 5 and $10 \%$ strain in moderate cases and up to $50 \%$ in extreme squeezing conditions. Typically, extreme squeezing ground occurs when the drive is subparallel to foliation, the foliation spacing is thin (tens of millimetres), the intact rock strength is weak (unconfined compressive strength around $10 \mathrm{MPa}$ ) and slippery or swelling minerals are present within the rock mass.

\subsection{Current engineering approach to ground support design in squeezing ground conditions}

An engineering approach to ground support design in squeezing ground is still lacking in the mining industry. Recent research and development work from Hadjigeorgiou and co-workers within Agnico Eagle Mines have concentrated in characterising squeezing ground behaviour and producing strain predicting charts as a function of ground conditions (Figures 5 and 6).
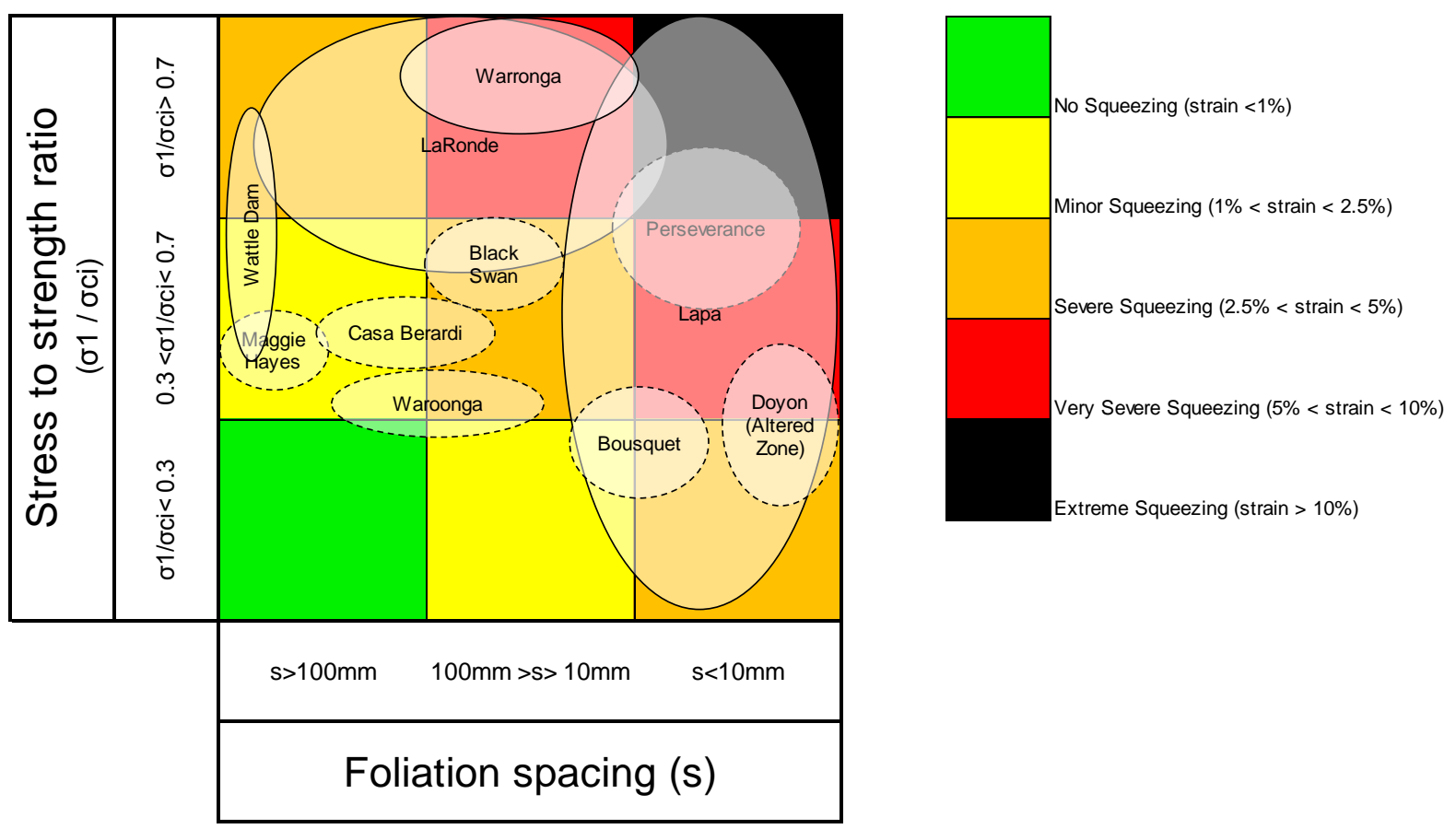

Figure 5 Hard rock squeezing index when foliation is subparallel $\left(0-25^{\circ}\right)$ to the drive (Mercier-Langevin \& Hadjigeorgiou 2011) 


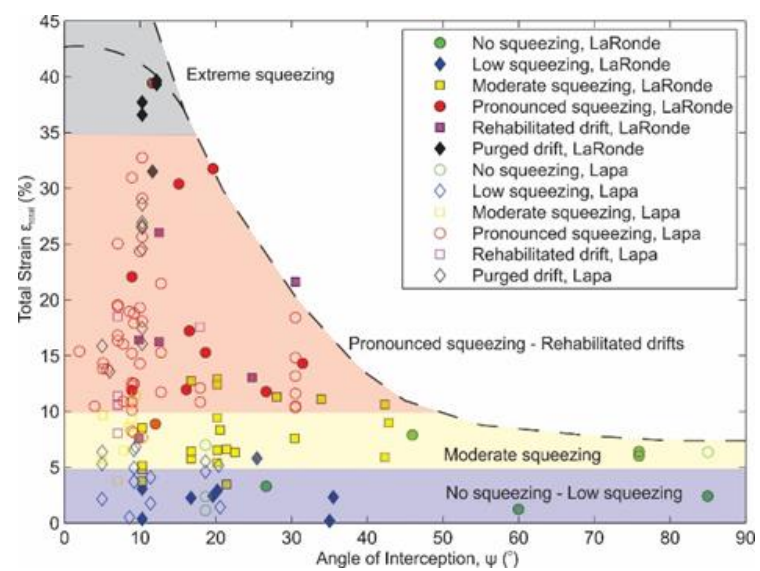

(a)

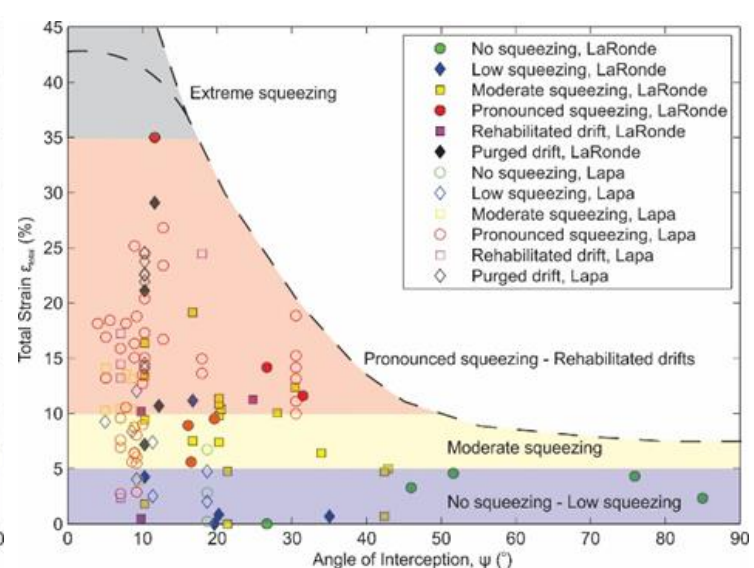

(b)

Figure 6 Forecasting squeezing ground convergence. (a) Wall to wall; and, (b) Back to floor, based on the angle of interception between the foliation and the drive (Karampinos \& Hadjigeorgiou 2015a)

Recent literature (Marlow \& Mikula 2013; Woolley \& Andrews 2015; Varden \& Woods 2015; Talbot \& Burke 2013 , and others) also provides description and guidance on the application of ground support systems that had some success in managing deformation/convergence and reduce the amount of ground support rehabilitation work. Many used yielding reinforcement including: cable bolts, mesh over reinforced shotcrete, mesh straps and Osro straps, as well as special techniques such as shotcrete arches, shotcrete pillars and umbrella arches (spiling). However, none of these offer a quantitative ground support design method for squeezing ground conditions.

\subsection{Gaps in the current engineering approach to ground support design in squeezing ground conditions}

Although significant progress has been made in forecasting convergence in squeezing ground, there is still no deterministic or empirical method for designing ground support in squeezing ground.

There are a few research questions that need to be resolved to improve current guidelines and provide a reliable framework for developing empirical rules. For example, the relationship between bolt spacing and surface support requirements is critical for the design of ground support systems in squeezing ground.

Cable bolts, and de-bonded cable bolts, are often used to slow down convergence in extreme squeezing ground, but their effect is unclear and yet to be quantified. In fact, the need for de-bonding reinforcement raises the interesting question of whether or not de-bonding is necessary. In theory, de-bonding is required when the convergence exceeds the capacity of a fully bonded reinforcement. In practice, a thick layer of crushed rock (from 2-6 $\mathrm{m}$ deep) often exists in squeezing ground and some degrees of natural de-bonding of the reinforcement elements occur as a result of convergence.

\subsection{Ground support design in squeezing ground conditions - where to from here?}

Now that we can forecast the convergence, we need to be able to calculate the deformation capability of ground support as a system. Karampinos and co-workers have spent a few years to explicitly model ground support in squeezing ground at Lapa and LaRonde mines (Karampinos et al. 2014, 2015a, 2015b, 2016). They have managed to replicate satisfactorily the complex squeezing mechanism, and calibrate the model including the ground support deformation. Having developed a calibrated model offers a unique opportunity to do numerical ground support trials in squeezing ground and better understand the deformation characteristics of different ground support systems in different squeezing conditions. This can serve as a basis for developing quantitative guidelines for ground support in squeezing ground. 


\section{$5 \quad$ Concluding remarks}

Ground support is one of the best mitigation measures to address rockfall risks. In many developed countries, ground support practices have gradually evolved towards conservative designs due to the low risk tolerance to rockfalls.

When looking at the opportunities for ground support optimisation without reducing safety, deficiencies in ground support design and our ability to assess their reliability become readily apparent.

Whether dealing with normal, rockburst-prone or squeezing ground conditions, several gaps in the design methods and practices at mine site have been identified. The technologies requiring further research and development have also been outlined. The collaborative GSSO research project started in 2013 and is undertaking a second phase to address some of these technology gaps.

\section{Acknowledgement}

The author thanks his GSSO colleagues and sponsors. In particular, GSSO Phase 1 major sponsors include: Glencore Mount Isa Mines, Independence Group NL, Codelco Chile, MMG Limited, the Minerals Research Institute of Western Australia, and the Australian Centre for Geomechanics. GSSO Phase 1 minor sponsors include: Jennmar Australia, DYWIDAG-Systems International Pty Ltd, Fero Strata Australia, Golder Associates Pty Ltd, Geobrugg Australia Pty Ltd, and Atlas Copco Australia Pty Ltd.

GSSO Phase 2 sponsors include the following major sponsors: Independence Group NL, Gold Fields of Australia Pty Ltd, BHP Olympic Dam, Newcrest Cadia Valley Operations, Agnico Eagle LaRonde mine, lamgold Westwood Mine, and the Minerals Research Institute of Western Australia. GSSO Phase 2 minor sponsors include: Jennmar Australia, DYWIDAG-Systems International Pty Ltd, Fero Strata Australia, Sandvik Mining and Rock Technology, Garock Ground Support Innovation, and New Concept Mining Pty Ltd.

\section{References}

Baecher, GB \& Christian, JT 2003, Reliability and Statistics in Geotechnical Engineering, John Wiley \& Sons, Chichester.

Durrheim, RJ 2012, 'Functional specifications for in-stope support based on seismic and rockburst observations in South African mines', in Y Potvin (ed.), Proceedings of the Sixth International Seminar on Deep and High Stress Mining, Australian Centre for Geomechanics, Perth, pp. 41-55.

Durrheim, RJ, Milev, A, Spottiswoode, SM \& Vakalisa, B 1998, Improvement of Worker Safety Through the Investigation of the Site Response to Rockbursts, SIMRAC GAP Project 201, Mine Health and Safety Council, Johannesburg, viewed 4 August 2017, http://www.mhsc.org.za/sites/default/files/gap201.pdf

Grimstad, E \& Barton, N 1993, 'Updating the Q-system for NMT', in C Kompen, SL Opsahl \& SL Berg (eds), Proceedings of the International Symposium on Sprayed Concrete, Norwegian Concrete Association, Oslo, p. 21.

Harris, PH \& Wesseloo, J 2015, mXrap, version 5, Australian Centre for Geomechanics, The University of Western Australia, Perth, http://mxrap.com/

Heal, D 2010, Observations and Analysis of Incidences of Rockburst Damage in Underground Mines, PhD thesis, The University of Western Australia, Perth.

Joughin, WC 2017, 'Dealing with uncertainty and risk in the design of deep and high stress mining excavations', Proceedings of the Eighth International Conference on Deep and High Stress Mining, in J Wesseloo (ed.), Australian Centre for Geomechanics, Perth, pp. 489-507.

Kaiser, PK \& Cai, M 2013, 'Critical review of design principles for rock support in Burst-prone ground - time to rethink!', in Y Potvin \& B Brady (eds), Proceedings of the Seventh International Symposium on Ground Support in Mining and Underground Construction, Australian Centre for Geomechanics, Perth, pp. 3-37.

Kaiser, PK, McCreath, DR \& Tannant, DD 1996, Canadian Rockburst Support Handbook, Canadian Mining Industry Research Organization, Sudbury.

Karampinos, E, Hadjigeorgiou, J \& Turcotte, P 2015b, 'Management of squeezing ground conditions at Laronde Mine', Proceedings of the 13th ISRM International Congress on Rock Mechanics, International Society for Rock Mechanics, Lisbon.

Karampinos, E, Hadjigeorgiou, J \& Turcotte, P 2016, 'Discrete element modelling of the influence of reinforcement in squeezing conditions in a hard rock mine', Rock Mechanics and Rock Engineering, vol. 49, no. 12, pp. 4869-4892.

Karampinos, E, Hadjigeorgiou, J, Turcotte, P, Drolet, M-M \& Mercier-Langevin, F 2014, 'Empirical and numerical investigation on the behaviour of foliated rock masses under high stress conditions', in M Hudyma \& Y Potvin (eds), Proceedings of the Seventh International Conference on Deep and High Stress Mining, pp. 345-361. 
Karampinos, E, Hadjigeorgiou, J, Turcotte, P \& Mercier-Langevin, F, 2015a 'Large-scale deformation in underground', Journal of The Southern African Institute of Mining and Metallurgy, vol. 115, no. 7, pp. 645-652.

Lang, A \& Stubley, C 2003, 'Rock falls in Western Australian underground metalliferous mines', Proceedings of the 2nd Biennial Workshop on Ground Control in Mines, The Chamber of Minerals and Energy of Western Australia, Perth, Section 1.

Langford, JC \& Diederichs, MS 2011, 'Application of reliability methods in geological engineering design', Proceedings of the 2011 Pan-Am GCS Geotechnical Conference, Canadian Geotechnical Society Publisher, Richmond.

Langford, JC \& Diederichs, MS 2013, 'Reliability-based approach to tunnel lining design using a modified Point Estimate Method', International Journal of Rock Mechanics and Mining Sciences, vol. 60, pp. 263-276.

Langford, JC, Diederichs, MS \& Hutchinson, JH 2012, 'Reliability-based approach to support design for underground works', Proceedings of the Tunnelling Association of Canada Conference, Tunnelling Association of Canada Conference, Richmond.

Low, BK \& Einstein, HH 2013, 'Reliability analysis of roof wedges and rockbolt forces in tunnels', Tunneling and Underground Space Technology, vol. 38, pp. 1-10.

Marlow, P \& Mikula, PA 2013, 'Shotcrete ribs and cemented rock fill ground control methods for stoping in weak squeezing rock at Wattle Dam Gold Mine', in Y Potvin \& B Brady (eds), Proceedings of the Seventh International Symposium on Ground Support in Mining and Underground Construction, Australian Centre for Geomechanics, Perth, pp. 133-147.

Mercier-Langevin, F \& Hadjigeorgiou, J 2011, 'Towards a better understanding of squeezing potential in hard rock mines', Mining Technology, Transactions of the Institutions of Mining and Metallurgy: Section A, vol. 120, no. 1, pp. 36-44.

Mikula, PA 2012, 'Progress with empirical performance charting for confident selection of ground support in seismic conditions', in Y Potvin (ed.), Proceedings of the Sixth International Seminar on Deep and High Stress Mining, Australian Centre for Geomechanics, Perth, pp. 71-89.

Mikula, PA \& Gebremedhin, B 2017, 'Empirical selection of ground support for dynamic conditions using charting of support performance at Hamlet mine', in J Wesseloo (ed.), Proceedings of the Eighth International Conference on Deep and High Stress Mining, Australian Centre for Geomechanics, Perth, pp. 625-636.

Milev, AM, Spottiswoode, SM \& Stewart, RD 1999, 'Dynamic response of the rock surrounding deep level mining excavations', Proceedings of the 9th ISRM International Congress on Rock Mechanics, A.A. Balkema, Rotterdam, pp. 1109-1114.

Morissette, P \& Hadjigeorgiou, J 2017, 'The development of a ground support strategy for deep mines subjected to dynamic loading conditions', in J Wesseloo (ed.), Proceedings of the Eight International Conference on Deep and High Stress Mining, Australian Centre for Geomechanics, Perth, pp. 651-665.

Morissette, P, Hadjigeorgiou, J, Punkkinen, AR \& Chinnasane, DR 2014, 'The influence of change in mining and ground support practice on the frequency and severity of rockbursts', in M Hudyma \& Y Potvin (eds), Proceedings of the Seventh International Seminar on Deep and High Stress Mining, Australian Centre for Geomechanics, Perth, pp. 165-177.

Morissette, P, Hadjigeorgiou, J \& Thibodeau, D 2012, 'Validating a support performance database based on passive monitoring data', in Y Potvin (ed.), Proceedings of the Sixth International Seminar on Deep and High Stress Mining, Australian Centre for Geomechanics, Perth, pp. 27-39.

Oreste, P 2005, 'A probabilistic design approach for tunnel support', Computers and Geotechnics, vol. 32, pp. 520-534.

Ortlepp, WD \& Stacey, TR 1998, Testing of Tunnel Support: Dynamic Load Testing of Rockbolt Elements to Provide Data for Safer Support Design, SIMRAC GAP Project 423, Mine Health and Safety Council, Johannesburg, viewed 4 August 2017, http://www.mhsc.org.za/sites/default/files/gap423.pdf

Ortlepp, WD \& Stacey, TR 1997, Testing of tunnel support: dynamic load testing of rock support containment systems, SIMRAC GAP Project 221, Safety in Mines Research Advisory Committee.

Palmstrom, A \& Broch, E 2006, 'Use and misuse of rock mass classification systems with particular reference to the Q-system', Tunnelling and Underground Space Technology, vol. 21, pp. 575-593.

Player, JR, Morton, EC, Thompson, AG \& Villaescusa, E 2008b, 'Static and dynamic testing of steel wire mesh for mining applications of rock surface support', Proceedings of the 6th International Symposium on Ground Support in Mining and Civil Engineering Construction, in TR Stacey \& D Malan (eds), The Southern African Institute of Mining and Metallurgy, Johannesburg, pp. 693-706.

Player, JR, Thompson, AG \& Villaescusa, E 2008a, 'Dynamic testing of reinforcement system', in TR Stacey \& D Malan (eds), Proceedings of the 6th International Symposium on Ground Support in Mining and Civil Engineering Construction, The Southern African Institute of Mining and Metallurgy, Johannesburg, pp. 581-595.

Player, JR, Villaescusa, E \& Thompson, AG 2009, 'Dynamic testing of friction rock stabilisers', in M Diederichs \& G Grasselli (eds), Proceedings of the 3rd Canada-US Rock Mechanics Symposium and 20th Canadian Rock Mechanics Symposium, paper 4027.

Player, JR, Villaescusa, E \& Thompson, AG 2013, 'Dynamic testing of fully grouted threaded bar - resin and cement grouted', in Y Potvin \& B Brady (eds), Proceedings of the Seventh International Symposium on Ground Support in Mining and Underground Construction, Australian Centre for Geomechanics, Perth, pp. 247-264.

Potvin, Y 2010, Ground Support in Underground Mining, unpublished PowerPoint presentation, Australian Centre for Geomechanics Course 1006, 25-27 August 2010, Perth.

Potvin, Y \& Hadjigeorgiou, J 2015, 'Empirical ground support design of mine drives', in Y Potvin (ed.), Proceedings of the International Seminar on Design Methods in Underground Mining, Australian Centre for Geomechanics, Perth, pp. 419-430.

Potvin Y \& Hadjigeorgiou J 2016, 'Selection of ground support for mining drives based on the Q-system', in E Nordlund, TH Jones \& A Eitzenberger (eds), Proceedings of the 8th International Symposium on Ground Support in Mining and Underground Construction, Luleå University of Technology, Sweden.

Potvin, Y \& Wesseloo, J 2013, 'Towards an understanding of dynamic demand on ground support', Journal of the Southern African Institute of Mining and Metallurgy, vol. 113, no. 12, pp. 913-922. 
Potvin, Y, Wesseloo, J \& Heal, D 2010, 'An interpretation of ground support capacity submitted to dynamic loading', Mining Technology, Transactions of the Institutions of Mining and Metallurgy: Section A, vol. 119, no. 4, pp. 233-245.

Rocscience Inc. 2012, UnWedge, Rocscience Inc., Toronto, viewed 4 August 2017, https://www.rocscience.com/rocscience/ products/unwedge

Stacey, TR 2012, 'Philosophical view on the testing of rock support for rockburst conditions', Proceedings of the Second Southern Hemisphere International Rock Mechanics Symposium, The Southern African Institute of Mining and Metallurgy, pp. 227-247.

Sweby, GJ, Dight, PM \& Potvin, Y 2016a, 'A numerical modelling case study - correlation of ground support instrumentation data with a three dimensional inelastic model', in E Nordlund, TH Jones \& A Eitzenberger (eds), Proceedings of the 8th International Symposium on Ground Support in Mining and Underground Construction, Luleå University of Technology, Sweden.

Sweby, GJ, Dight, PM, Potvin, Y \& Gamble, N 2016b, 'An instrumentation project to investigate the response of a ground support system to stoping induced deformation', in E Nordlund, TH Jones \& A Eitzenberger (eds), Proceedings of the 8th International Symposium on Ground Support in Mining and Underground Construction, Luleå University of Technology, Sweden.

Talbot JF, Burke J 2013, 'Mining in consolidated and presupported karstified ground conditions', in B Brady \& Y Potvin (eds), Proceedings of the Seventh International Symposium on Ground Support in Mining and Underground Construction, Australian Centre for Geomechanics, Perth, pp. 149-162.

Varden, RP \& Woods, MJ 2015, 'Design approach for squeezing ground', in Y Potvin (ed.), Proceedings of the International Seminar on Design Methods in Underground Mining, Australian Centre for Geomechanics, Perth, pp. 489-504.

Villaescusa, E 2014, Geotechnical Design for Sublevel Open Stoping, CRC Press, Boca Raton, 519 p.

Villaescusa, E, Thompson, AG \& Player, JR 2013a, 'A decade of ground support research at the WA School of Mines', in Y Potvin \& B Brady (eds), Proceedings of the Seventh International Symposium on Ground Support in Mining and Underground Construction, Australian Centre for Geomechanics, Perth, pp. 233-245.

Villaescusa, E, Thompson, AG \& Player, JR 2013b, 'Static and dynamic testing of welded and woven mesh for rock support', in B Brady and $Y$ Potvin (eds), Proceedings of the Seventh International Symposium on Ground Support in Mining and Underground Construction, Australian Centre for Geomechanics, Perth, pp. 187-196.

Villaescusa, E, Thompson, AG, Player, JR \& Morton, E 2010, Dynamic Testing of Ground Support Systems, Phase 2 - Final Report MERIWA Project M349A, Minerals Research Institute Of Western Australia, Perth.

Villaescusa, E, Varden, R \& Hassell, R 2008 'Quantifying the performance of resin anchored rock bolts in the Australian underground hard rock mining industry', International Journal of Rock Mechanics \& Mining Sciences, vol. 45, no. 1, pp. 94-102.

Wesseloo, J \& Joughin, WC 2017, in Y Potvin \& J Hadjigeorgiou (eds), Ground Support Systems Optimisation, vol. 1, Ground Support Design, Australian Centre for Geomechanics, Perth, in press.

Wolley CE \& Andrews, P 2015, 'Short term solution to squeezing ground at Agnew Gold Mine', in Y Potvin (ed.), Proceedings of the International Seminar on Design Methods in Underground Mining, Australian Centre for Geomechanics, Perth, pp. 199-214. 